\title{
Culture Economy for Economic Development: Assesments on Cultural Heritage in Turkey ${ }^{1}$
}

\author{
Hilal Yuldurtr Keser, PhD \\ Uludag University, Turkey
}

doi: 10.19044/esj.2016.v12n28p38 URL:http://dx.doi.org/10.19044/esj.2016.v12n28p38

\begin{abstract}
Cultural economics can be grouped under four main headings: cultural heritage, arts, media (film, radio, television, music, journalism, and publishing) and creative services (design, advertising, new media, architecture, and software). These cultural goods and services that constitute the cultural economy interact with other industries. This interaction has an impact on the development process by creating added value for the economy through the multiplier effect. The cultural industries that are also referred to as creative industries tend to have a significant economic impact, mainly in terms of providing employment and increasing exports. In contrast, tourism, textiles, jewellery, toys, and many other suppliers ensure the development of these industries by creating indirect economic impacts. In this context, firstly cultural economics and its scope will be discussed, and its relationship with economic development will be explained. Next, referring to examples of tangible and intangible cultural heritage, the impact of cultural economics on the economic development of Turkey will be explored, specifically with regards to the Cappadocia region.
\end{abstract}

Keywords: Culture, Cultural Economics, Cultural Heritage

\section{Introduction}

The concept of cultural economics has recently become more pervasive, especially in the last quarter century. The rapid and radical changes in various cultural industries and sectors - such as audio-visual media, information technology, recording and digital technologies, and tourism - have had a great impact on this trend. The rapid transition of some societies into contexts of electronics, as well as virtual and digital culture, is the result of specific dynamics. In particular, the new cultural contexts have brought innovative systems, tools, products, and services. The existing

${ }^{1}$ First edition of this article presented in "International Business Finance and Marketing Research Conference 2016” in Zürich (4-6 August 2016) 
cultural memory has quickly begun a process of transformation to the electronic, virtual, and digital media. As a result, cultural creation, transmission, and consumption have become markedly different than they were in the past (Özdemir, 2012).

Cultural economics has provided many regions of varying levels of development in the modern world with opportunities to create employment and income. The regions are able to market, grow employment, and generate income by transforming their sources of natural and cultural heritage, arts, and creative/cultural products into centres of production, utilizing modern information and communication technologies to do so. Moreover, cultural economics enables the establishment of a social learning platform that will make it possible to increase and diversify cultural knowledge in the region. It allows people to participate in social, economic, and cultural life in a way that will increase their individual welfare and potential; they will be able to adopt ways of living that differ from the patterns they are used to, and to develop a creative dialogue. Overall, this development of the cultural environment will increase the prosperity of human life (Kumral and Güçlü, 2013).

Turkey is ranked 16th in the world for its sources of natural and cultural heritage. These play an important role in the development process due to the social and economic effects they create in the economy. From this point of view, this study will firstly refer to Turkey's cultural economics and its scope, as well as explain its relationship to economic development. Next, by evaluating cultural economics in Turkey with regards to natural and cultural heritage, the case of Cappadocia, one of Turkey's most significant natural and cultural heritage sites, will be discussed.

\section{Cultural Economics and Its Scope}

The concept of culture "is composed of a harmonious total value of the tangible and intangible assets specific to that nation established by various accumulations throughout historical development and useful for a nation to acquire personality and for determining the difference with the other nations" (Bilgiç, 1977; Işık, 2009). In this context, culture can be defined as the common behaviours that guide the social structure of a society and cause that society to acquire personality, traditions-customs, morals, ways of performing work, and common values (Ekşioğlu, 2013). In the new competitive environment that comes with globalization, some countries consider culture as one of the main tools of empowering their images and socio-economic performances. In fact, culture has a close relationship with the science of economics. Economy includes all kinds of values, production, and consumption processes. Considering this, all cultural fields, traditions, elements, and activities enter the investigation area of economics and 
constitute the subjects of "cultural economics," which is a sub-topic of economics (Özdemir, 2012). Cultural economics, in general, is composed of activities and sectors covering cultural heritage, arts, media, and creative services.

Specifically, UNESCO defines cultural economics using the concepts of "cultural domains" and "related domains." Cultural domains cover all of the cultural activities and goods and services included in the cultural cycle (production and propagation of the culture). Cultural domains are expressed as follows:

i. Cultural and natural heritage: Museums, including virtual museums, archaeological and historical sites;

ii. Performance and celebrations: Performing arts, music, festivals, and fairs;

iii. Visual arts and crafts: Fine arts, photography, and crafts;

iv. Books and publications: Books, newspapers, magazines, other printed materials, and libraries (also virtual);

v. Audio visual and interactive media: Film, video, television and live Internet streaming, Internet podcasting, and video games (also online);

vi. Design and creative services: Fashion design, graphic design, internal design, architectural services, and advertising services;

vii. Intangible cultural heritage: Customs and traditions, beliefs, festivals, ceremonies, celebrations, and language.

In contrast, related domains are formed by expanding the definition of culture to cover social and recreational activities. Although they feature cultural content, the main components of related domains are non-cultural. These are specified as:

viii. Tourism;

ix. Sports and recreation.

Moreover, there are three additional areas relevant to both cultural and related domains that play key roles in the cultural cycle. These are education, vocational training, and the archiving and preserving of equipment and supportive materials (UNCTAD, 2010; Kumral and Güçlü, 2013). Figure 1 shows the areas of cultural and related domains. 
Figure 1 Cultural and Related Domains

\begin{tabular}{|c|c|c|c|c|c|c|c|}
\hline \multicolumn{6}{|c|}{ CULTURAL DOMAINS } & \multicolumn{2}{|c|}{ RELATED DOMAINS } \\
\hline $\begin{array}{l}\text { A. CULTURAL } \\
\text { and NATURAL } \\
\text { HERTTAGE } \\
\text { - Museums (also } \\
\text { vitual) } \\
\text {-Archeological and } \\
\text { Historical Places } \\
\text { - Cultural } \\
\text { Lendscapes } \\
\text { - Natural Herltage }\end{array}$ & $\begin{array}{l}\text { B. } \\
\text { PERFORMANCE } \\
\text { and } \\
\text { CELEBRATION } \\
\text { - Performing Arts } \\
\text { - Music } \\
\text { - Festivals, Fairs } \\
\text { and Feasts }\end{array}$ & $\begin{array}{l}\text { C. VISUAL ARTS } \\
\text { and CRAFTS } \\
\text { - Fine Arts } \\
\text { - Photography } \\
\text { - Crafts }\end{array}$ & $\begin{array}{l}\text { D. Books and } \\
\text { PREss } \\
\text { - Books } \\
\text { - Newspaper and } \\
\text { Magazine } \\
\text { - Other printed } \\
\text { matter } \\
\text { - Library (also } \\
\text { virual) } \\
\text { - Book Fairs }\end{array}$ & $\begin{array}{l}\text { E. AUDIO-VIISUAL } \\
\text { and } \\
\text { INTERACTTVE } \\
\text { MEDIA } \\
\text {-Film and Video } \\
\text { - TV and Radio } \\
\text { (also Internet live } \\
\text { streaming) } \\
\text { - Internet } \\
\text { podcasting } \\
\text {-Video Games }\end{array}$ & 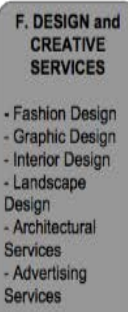 & $\begin{array}{l}\text { G. TOURISM } \\
\text { - Charter travel } \\
\text { and tourist } \\
\text { services } \\
\text { - Hospitality and } \\
\text { accommodation }\end{array}$ & $\begin{array}{l}\text { H. SPORTS and } \\
\text { RECREATION } \\
\text { - Sports } \\
\text { - Physical fitness } \\
\text { and well being } \\
\text { - Amusement } \\
\text { and Theme } \\
\text { Parks } \\
\text { - Gambling }\end{array}$ \\
\hline \multicolumn{6}{|c|}{$\begin{array}{l}\text { INTANGIBLE CULTURAL HERITAGE } \\
\text { (oral traditions and expressions, rituals, languages, social practices) }\end{array}$} & \multicolumn{2}{|c|}{$\begin{array}{l}\text { INTANGIBLE CULTURAL } \\
\text { HERITAGE }\end{array}$} \\
\hline \multicolumn{6}{|c|}{ EDUCATION and TRAINING } & \multicolumn{2}{|c|}{ EDUCATION and TRAINING } \\
\hline \multicolumn{6}{|c|}{ ARCHIVING and PRESERVING } & \multicolumn{2}{|c|}{ ARCHIVING and PRESERVING } \\
\hline \multicolumn{6}{|c|}{ EQUIPMENT and SUPPORTING MATERIALS } & \multicolumn{2}{|c|}{$\begin{array}{l}\text { EQUIPMENT and SUPPORTING } \\
\text { MATERRALS }\end{array}$} \\
\hline
\end{tabular}

Source: UNCTAD (2010)

In recent years, the concept of "creative and cultural industries" has been elaborated on considerably, along with the cultural economy. This concept can be expressed as a general classification covering the activities that are within the scope of intellectual property law, such as music, dance, theatre, literature, audio-visual media, design, informatics, and digital technology, in which creativity is used as added value (Aksoy and Enlil, 2011). However, the current dominant view is the idea that the future of prosperity and economic development depends on creativity and the creative industries that drive the creative economy, and a shift in policy circles is responsible for this (Towse, 2011).

\section{Cultural Economics and Its Relationship with Economic Development}

Economic development is defined as the process of structural transformation in the social, cultural, and political fields, independent of production and revenue growth in a country. When the historical evolution of economic development is considered, it is clear that it is generally defined in light of economic indicators and improvement in this direction. However, neglecting and leaving the social structures incomplete while defining a country's economic development has hampered the establishment of the conceptual environment, as well as the formation of its content, to some extent. Many economists, from Durkheim to Smith, Schumpeter, and Marx, 
have generated approaches and opinions concerning the concept of development. However, as many economists have neglected the cultural dimensions of development, the concept-which had continued its rise until the 1970s - began to decline following a series of shocks and crises. Since it has been tied so closely with economic growth in its general outlines, it has remained inadequate for explaining depressions, and the concept has been avoided for many years (Erbay, 2013). In actuality, culture is one of the most important factors in achieving economic development. Indeed, in a report published by the World Bank in 1999, it was suggested that culture is the key to sustainable economic growth and development. According to the World Bank report, culture influences economic growth and development in four main ways:

i. Cultural backlog and production create new opportunities for poor communities;

ii. It facilitates the provision and adoption of economic development at the local level;

iii. Existing cultural assets are preserved and income is generated (tourism income and acceleration of urban development);

iv. Human and social capital stock are strengthened, which means that employment and productivity increases simultaneously by helping people in the low-income groups to improve their abilities and skills (World Bank, 1999).

In this context, the source of natural, cultural, and spiritual heritage, along with creative/cultural activities, provide important contributions to economic development. Furthermore, UNESCO agreements aimed at preserving the diversity of both tangible and intangible cultural heritage and cultural expressions are critical aspects of ensuring sustainable economic development, especially for developing countries with their own cultural treasures (Özdemir, 2012).

During the past ten years, statistics, indicators, and data on the cultural sector, and also on operational activities, have emphasized that culture can be a driving force for development, with resulting social, economic, and environmental impacts on all aspects of a community. The contribution of cultural sectors to the economy and to reducing poverty is of particular importance. For generating income, generational cultural heritage, cultural and creative industries, sustainable cultural tourism, and cultural infrastructure can be considered strategic tools, especially for developing countries with rich cultural heritage and important labour forces. Statistics underline the importance of cultural and creative industries, showing that they represent one of the most rapidly expanding sectors in the global economy, with a growth rate of $17.6 \%$ in the Middle East, $13.9 \%$ in Africa, 
11.9\% in South America, 9.7\% in Asia, 6.9\% in Oceania, and 4.3\% in North and Central America (UN, 2012).

In its Creative Economy Report 2010, UNCTAD specifies a ten-item policy recommendation regarding how creative industries can support a country's economic growth and development. In this context, the message it intends to communicate to developing countries has been expressed as:

The creative industries have been relatively less affected by the economic crisis in 2008. The creative industries are of importance for the developing countries to be able to do the economic bounce that they desire. The countries should make the necessary administrative and legal arrangements in order to promote and improve the creative industries and cultural economics, support the establishment of the cultural capital with long-term policy. (UNCTAD, 2010; Ekşioğlu, 2013)

In another study, Ekşioğlu (2013) reached the following conclusions when examining the economic effect of cultural activities with input-output analysis:

i. Cultural backlog nourishes creativity in economic production.

ii. The infrastructure development accelerates in regions where cultural investments are made. The domestic investments increase, and regional economic development becomes easier.

iii. They ensure the generation of revenue from existing cultural assets, tourism, and foreign trade. The cultural assets contribute to the branding and expansion of local and touristic attractiveness of the places where they exist.

iv. By interacting with other sectors in the economy, the cultural capital creates a multiplier effect on the economy. Specifically, it increases employment and revenue.

\section{Cultural Economics and Economic Development in Turkey: Evaluations Focused on Cultural Heritage}

Cultural economics has begun to emerge in certain regions in Turkey in recent years. In spite of this, it can be said that an overall official policy regarding cultural/creative industries and a comprehensive support system have not yet been developed in Turkey, unlike in countries such as the United Kingdom, Canada, Australia, New Zealand, Taiwan, South Korea, Singapore, Scotland, and China, which have all included cultural/creative industries in their national innovation strategies, or cities such as St. Petersburg, which aim to acquire knowledge with the European Union funds. According to research conducted by Lazzeretti et al. (2014), the cultural and creative industries that have important potential to play a role in innovation and economic development in Turkey have not yet reached desired levels. 


\section{Cultural Heritage in Turkey}

One of the most important indicators of countries' cultural economics potential is the possession of cultural heritage resources. As of 2015, there are 1,031 cultural and natural assets registered on the UNESCO World Heritage List, 802 of which are cultural, 197 are natural, and 32 are mixed (cultural/natural) assets. This number has been increasing as a result of the annual World Heritage Committee meeting. Turkey currently possesses 15 cultural assets on the World Heritage List, as specified by UNESCO. As noted, with the cultural assets it owns, Turkey was ranked 16th among 141 countries in the Travel \& Tourism Competitiveness Index, published by WEFORUM at the beginning of 2015. In addition, the intangible cultural heritage owned by the country is another important indicator of its potential in terms of cultural economics. Currently, Turkey has 12 intangible cultural heritage items on the List of Intangible Cultural Heritage published by UNESCO, and has been ranked 6th among countries of the world in the Travel \& Tourism Competitiveness Index (WEFORUM, 2015).

Table 1 Tangible and Intangible World Heritage in Turkey

\begin{tabular}{|c|c|}
\hline Tangible World Heritage List & Intangible World Heritage List \\
\hline Natural and Cultural (2) & Meddahlik (Art of Public Story Telling) \\
Tradition (2008) \\
Cappadocia (1985) & Mevlevi Semah Ceremony (2008) \\
Hierapolis-Pamukkale (1988) & (2009) \\
Cuşıltural (13) & Karagöz Shadow Theater (2009) \\
Historic Areas of Istanbul (1985) & Newroz (Common Tradition for Spring \\
Great Mosque and Hospital of Divriği & Festival, also in Azerbaijan, India, Iran, \\
(1985) & Kirgyzstan, Uzbekstan, and Pakistan) (2009) \\
Hattusha: The Hittite Capital (1986) & Traditional Conversations (Sohbet) and \\
Nemrut Dağ (1987) & Meetings (Yaren, Barana, Sira Nights, and \\
Xanthos-Letoon (1988) & Others) (2010) \\
City of Safranbolu (1994) & Alevi-Bektaşi Ritual Semah (2010) \\
Archaeological Site of Troy (1998) & Kirkpınar Oil Wrestling Festival (2010) \\
Selimiye Mosque and its Social Complex & Ceremonial Keskek Tradition (2011) \\
(2011) & Mesir Paste Festival (2012) \\
Neolithic Site of Çatalhöyük (2012) & Turkish Coffee Culture and Tradition (2013) \\
Pergamon and its Multi-Layered Cultural & Ebru, Turkish Art of Marbling (2014) \\
Landscape (2014) & \\
Bursa and Cumalıkız: The Birth of the & \\
Ottoman Empire (2014) & \\
Diyarbakır Fortress and Hevsel Gardens & \\
Cultural Landscape (2015) & \\
Ephesos (2015) & \\
\hline
\end{tabular}

Source: UNESCO (2016)

Turkey's tangible and intangible cultural heritage has played an important role in its economic development by enabling creative sectors and 
activities to emerge. The most significant effect of this is seen in tourism activities. Tourism is one of Turkey's most important sources of national income. As it features such diverse cultures in its population, Turkey hosts foreign tourists during each period of the year. The fact that foreign tourists prefer Turkey for cultural reasons, in addition to its sea and beach access, impacts its competitiveness positively. Additionally, this situation has also been an important factor in the attraction of culture-oriented foreign investments. The operation of chain hotels in the regions of Turkey where cultural heritage exists can be seen as an example of this. Furthermore, the development of the tourism industry can be specified as one of the most important reasons for the recent increase in employment rates. In particular, the regions where cultural heritage exists - and the holiday resorts are located - tend to be the places where the employment rates are the highest.

Lastly, these centres of tangible and intangible heritage in Turkey facilitate the emergence of cultural/creative products and services. Cultural activities, such as local festivals, rejoicings, and fairs held at certain times specific to these regions, stimulate the economy within the scope of creative services. While the cultural activities attract domestic and foreign tourists to these regions, they simultaneously enable the introduction of indigenous products and handicrafts, and subsequently provide grounds for export. The cultural activities held in many regions of Turkey have continued to increase. Figure 2 shows the values and the course of development of the annual export of cultural and recreational services in Turkey.

Figure 2 Values of Personal, Cultural, and Recreational Services (Services, Exports) in

Turkey, Annual, 2005-2015 (Million USD)

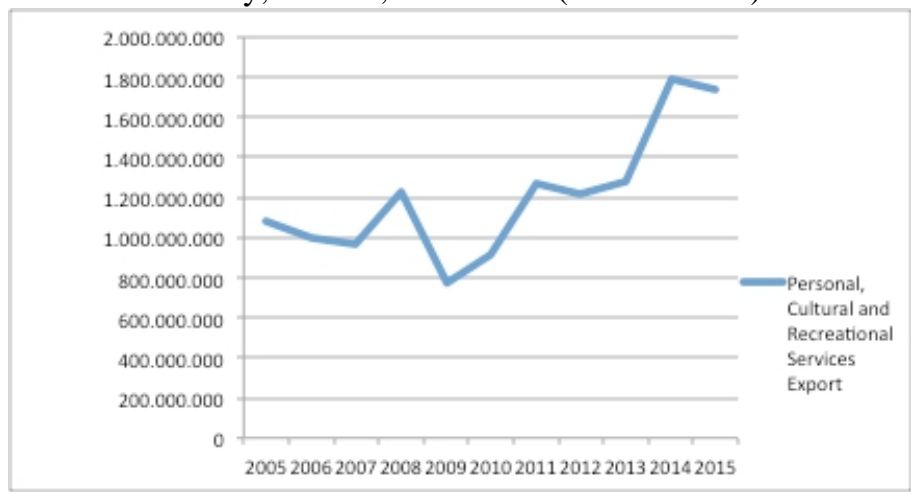

Source: TUİK (2016)

Among these exports, handicrafts have an important place in Turkey's cultural/creative industries. Products such as carpets, rugs, pottery, and china that emerge from indigenous cultures specific to Turkey attract intensive demand in the foreign market. In fact, according to the 2008 international trade data, while Turkey ranks 4th in the export of creative 
goods among developing countries, it ranks 1st in the export of creative services. The United Nations' Creative Economy Report 2010 presented the creative industries as a positive alternative for development, and has considered Turkey and Argentina as examples of developing countries in this regard (UNCTAD, 2010; Demir, 2014). Figure 3 shows the annual export values of major creative/cultural goods in Turkey.

Figure 3 Values of Creative Goods and Exports, Annual in Turkey, 2003-2012 (Million USD)

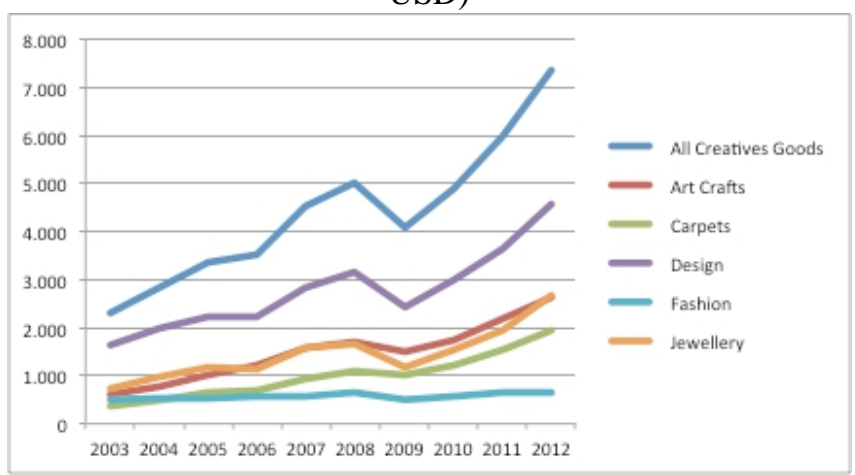

Source: UNCTAD Statistics (2016)

Beyond these exports, regions in Turkey where tangible cultural heritage exists have recently been important sites for films and television serials. Some of these regions have been utilized as natural film sets, primarily for foreign film makers, who conduct a part or all of their scene shots in Turkey. These films both stimulate the economy during the shooting period and increase the periodic employment rate. In addition, following their release, they vitalize the tourism industry by attracting local and foreign tourists to the region. Turkey has seized an important opportunity recently, and has added Hollywood films with huge budgets and celebrity casts to its list of cultural assets. Since 2011, Turkey has made important contributions to the development of tourism by hosting a total of 18 foreign shoots, including Skyfall, which exceeded 1 billion in box office returns; Argo, which received the Academy Award for Best Movie; Taken 2; and finally, the movie The Water Diviner, in which Russel Crowe both directed and undertook the leading role. Furthermore, in recent years, the featuring of indigenous cultural products in the films shot in these regions has allowed local culture to generate demand and increase the export of creative products. Although Turkey does not export cinematic films worldwide, it can be said that it is highly successful in the field of television serials. Numerous television serials shot in Turkey are exported internationally, mainly to Arab and Middle Eastern countries. The fact that some of these television serials span periods of more than two to three years only serves to increase the economic impacts they create. 


\section{The Case of Cappadocia}

Cappadocia is one of Turkey's most important natural and cultural heritage regions in Central Anatolia. It emerged 60 million years ago, formed by the erosion of the soft layers of lava and ash produced by three volcanoes: Erciyes, Hasandağı, and Güllüdağ. Over millions of years, winds and rains have carved the landscape into unique geological features. Cappadocia has been a permanent settlement site since the Chalcolithic Period, and the lands where the Hittites lived became one of the most important centres of Christianity in subsequent centuries. Its extraordinary rock formations create spaces that are warm in winter and cool in summer, thereby providing appropriate interior climatic conditions in all seasons.

Since 1985, the Cappadocia region has been included as a natural and cultural world heritage site on the UNESCO World Heritage List. Specifically, Göreme National Park, Göreme and Kaymaklı Underground Cities, Karain Dovecotes, Karlık Church, Yeşilöz Theodorou Church, and the Soğanlı Archeological Site have been designated as heritage sites (Republic of Turkey Ministry of Culture and Tourism, 2016). The fact that the Cappadocia region is listed among recognized natural and cultural heritage sites of the world has significantly affected tourism activities in the area. The region hosts approximately 2.5 million domestic and foreign tourists each year. One unique service in this region is "Balloon Tourism," which highlights the natural and cultural atmosphere of Cappadocia. Approximately 30 companies organize hot air balloon tours and approximately 500,000 tourists go ballooning every year in Cappadocia.

In addition to balloon tours, numerous activities have been carried out within the scope of creative/cultural services in the Cappadocia region. For instance, the Annual Türkmen Dining Table Feast in the Nevşehir city centre, the Hacı Bektaş-1 Veli commemoration ceremonies in the town of Hacı Bektaş, the vintage festivals and wine contests in the town of Ürgüp, and the International Handicrafts Festival in the town of Avanos can all be seen as examples of these activities.

Natural and cultural heritage is crucial to the survival of Cappadocia residents' occupations. For instance, besides keeping cultural heritage alive, Cappadocia's handicrafts - pottery, carpet (rug) weaving, handmade baby doll production, and onyx stone processing-have been important sources of income in the region as creative/cultural products. Demand for these products stems from both domestic and foreign tourists, and the products are exported to many countries.

Regarding the promotion of tourism, domestic and foreign television serials, films, and documentaries shot in the region have served as effective tools during the economic development process of the Cappadocia region. Since the film Medea, shot by the Italian director Pier Paolo Pasolini in 
1969, producers from Germany, Brazil, Saudi Arabia, the USA, China, India, Ukraine, Denmark, Bulgaria, Italy, South Korea, Russia, Indonesia, the Netherlands, Singapore, Belgium, the United Arab Emirates, Egypt, Malaysia, Croatia, England, Pakistan, Spain, Vietnam, Argentina, Taiwan, Canada, France, and Sweden have shot a total of 193 films, television serials, programs, documentaries, promotional spots, and advertising films in Cappadocia (Nevşehir Valiliği, 2016). Furthermore, in recent years, the Brazilian serial Salve Jorge has been shot in Cappadocia and watched by millions of people in Brazil, and America's most famous television face, Martha Stewart, even performed a program in the region-both of which have contributed significantly to Cappadocia's publicity. The film Kış Uykusu, which received the Golden Palm Prize at the Cannes Film Festival in 2014, was also shot in Cappadocia by Nuri Bilge Ceylan, who is one of the most prominent directors in Turkey (Republic of Turkey Ministry of Environment and Urbanization, 2016).

Overall, the designation of Cappadocia as a world heritage site by UNESCO has facilitated many activities that support the region's economic development. The production of creative/cultural products, primarily tourism activities nourished by the culture it owns, have prompted an increase in employment rates in the region. Additionally, the export of products and services has also increased, and these developments make the region attractive for investments. All of these developments work together to improve the welfare of the region's people, in addition to the increase in production and revenue, which constitute the basis of economic development.

\section{Conclusion}

Cultural economics, with its increasing importance over the 20th century, has become the most critical element of economic development in many areas. In the modern world, these countries consider culture to be one of the basic tools of strengthening their images and socio-economic performances in the shifting competitive environment. At this point, the areas of cultural economics gaining importance generally consist of cultural heritage, arts, media, and creative services.

Turkey, which is situated at the intersection of three continents and is home to diverse cultures, is a rich country in regards to tangible and intangible cultural heritage resources. According to the Travel \& Tourism Competitiveness Report 2015, published by the World Economic Forum, Turkey ranks 16th among the world's countries in tangible cultural heritage, and 6th in intangible cultural heritage. These sources of cultural heritage represent a great potential for Turkey's economic development. Although it is difficult to state that Turkey has been using this potential appropriately, it 
is obvious that it has shown significant improvements in recent years. The cultural heritage that Turkey owns, while primarily ensuring an increase in tourism activities, also leads to the production of creative/cultural products and services, and even to the export of these goods. Meanwhile, the increase in economic activities also improves the employment rate. Thus, the welfare of the people living in places where natural and cultural heritage exists is enriched, while at the same time increasing national income due to economic activities. Additionally, the regions with economic viability become attractive to investors.

Cappadocia, which is one of Turkey's most important cultural heritage sites, can be highlighted as a striking example of the economic impacts created by its cultural heritage. Tourism activities have been the most important source of income in Cappadocia recently, which has been considered a natural and cultural heritage site by UNESCO since 1985. This situation has vitalized the economic activities and tourism of Cappadocia in a unique way. Thus, among the components of cultural economics that a region owns, cultural and natural heritage resources support economic development by triggering an increase in tourism and entertainment services, promoting the production of creative/cultural products and services, increasing media activities, and reviving artistic activities.

\section{References:}

1. Aksoy, A. \& Enlil, Z. (2011) Kültür Ekonomisi Envanteri İstanbul 2010, Bilgi Üniversitesi Yayınları, İstanbul.

2. Bilgiç, E. (1977) 'Milli Kültür Anlayışı'’ Milli Kültür Dergisi, Vol. 1, No. 1 , Ocak.

3. Demir, E. M. (2014) 'Yaratıc1 Endüstriler,' Illef Journal, Vol. 1, No. 2, pp. 87-107.

4. Ekşioğlu, Ş. Z. (2013) 'Kültür ile İlgili Faaliyetlerin Ekonomik Etkisi,' EY International Congress on Economics I - Europe and Global Economic Rebalancing, Ankara.

5. Erbay, R. (2013) 'Ekonomik Kalkınmada Tarımın Rolü: Türkiye Üzerine Bir Değerlendirme,' Balkan Journal of Social Sciences, Vol. 2, No. 4.

6. Işık, A. (2009) 'Kültür ve Kalkınma: Vergi Kültürü Örneği,' Ege Akademik Bakış/Ege Academic Review, Vol. 9, No. 2, pp. 851-865.

7. Kumral, N. \& Güçlü, M. (2013) 'Kültür Ekonomisi ve Bölgesel Politika,' Ege University Working Papers, Working Paper No: 13 / 05.

8. Lazzeretti, L., Capone, F., \& Seçilmiş İ. E. (2014) Türkiye'de Yaratıcı ve Kültürel Sektörlerin Yapısı, Maliye Dergisi, No. 166 (Ocak-Haziran), pp. 195-220. 
9. Nevşehir Valiliği (2016) http://www.nevsehir.gov.tr/ (Accessed 10 April 2016)

10. Özdemir, N. (2012) Kültür Ekonomisi ve Yönetimi - Seçki, Hacettepe Yayınları, 1.b, Ankara.

11. Republic of Turkey Ministry of Culture and Tourism (2016) https://www.kultur.gov.tr (Accessed 16 March 2016)

12. Republic of Turkey Ministry of Environment and Urbanization (2016) http://www.csb.gov.tr/iller/nevsehir/ (Accessed 08 April 2016)

13. Towse, R. (2011) 'Introduction,' in Towse, R. (Ed.), A Handbook of Cultural Economies, Edward Elgar Publishing, Second Edition, United Kingdom.

14. TUİK - Turkish Statistical Institute (2016) http://www.turkstat.gov.tr (Accessed 18 May 2016)

15. UN - United Nations (2012) Culture: A Driver and Enabler of Sustainable

Development http://www.un.org/millenniumgoals/pdf/Think\%20Pieces/2_culture.p df (Accessed 20 May 2016)

16. UNCTAD - United Nations Conference on Trade and Development (2010) Creative Economy Report 2010, Geneva-New York.

17. UNCTAD - United Nations Conference on Trade and Development (2016), UNCTADStat, http://unctadstat.unctad.org/ (Accessed 26 April 2016)

18. UNESCO (2016) World Heritages Centre http://whc.unesco.org/ (Accessed 03 March 2016)

19. WEFORUM (2015) The Travel \& Tourism Competitiveness Report 2015

http://www3.weforum.org/docs/TT15/WEF_Global_Travel\&Tourism _Report_2015.pdf (Accessed 18 February 2016)

20. World Bank (1999) Culture and Sustainable Development: A Framework for Action, World Bank, Washingt on, DC. 